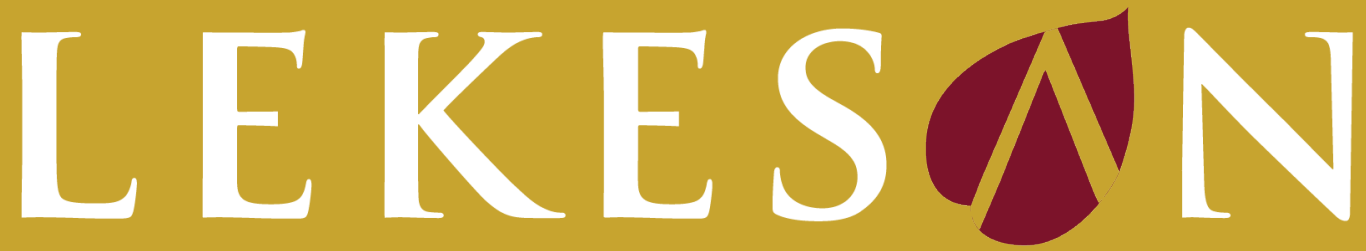

Interdisciplinary Journal of Asia Pacific Arts

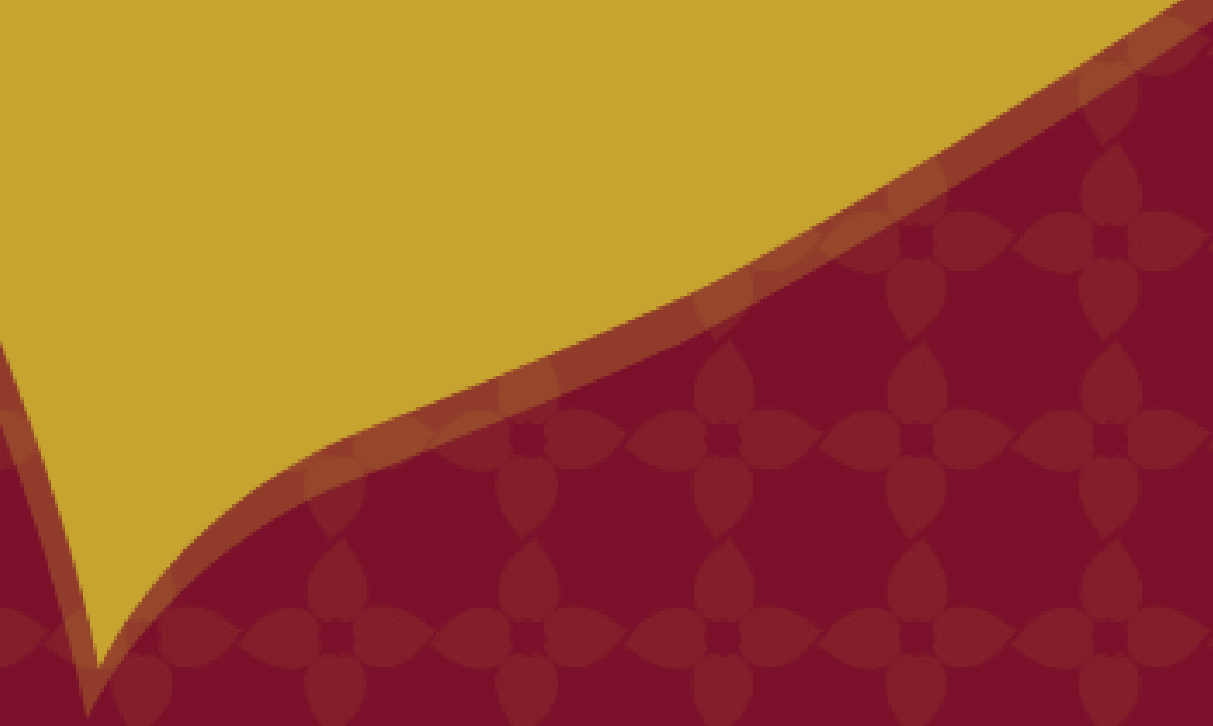

VOLUME 2, ISSUE 1, APRIL 2019

\title{
Drawing Pattern On Novels In Contemporary Art
}

I Made Jana

I Wayan Sujana

I Ketut Muka 


\author{
LEKESAN: INTERDISCIPLINARY JOURNAL OF ASIA \\ PASIFIC ARTS \\ jurnal.isi-dps.ac.id \\ ISSN: 2598-2192 (online) \\ Editorial Office \\ Indonesia Institute of The Arts Denpasar \\ Jalan Nusa Indah Denpasar 80235 \\ Phone +62-361-227316 ext 159 Fax +62-361-236100 \\ E-mail : penerbitan@isi-dps.ac.id
}

LEKESAN: INTERDISCIPLINARY JOURNAL OF ASIA PASIFIC ARTS

Is a peer-reviewed journal

All rights reserved. Apart from fair dealing for the purposes of study, research, criticism, or review, as permitted under the applicable copyright legislation, no part of this work may be reproduced by any process without written permission from the publisher. For permissions and other inquiries, please contact penerbitan@isi-dps.ac.id

\section{ARTICLE SUBMISSION}

Lekesan: interdisciplinary journal of asia pasific arts is published 2 (two) times a year, i.e. april and october. To find out more about the submission process, please visit http://jurnal.isi-dps.ac.id/index.php/lekesan

\section{ARTICLE PROCESSING CHARGES}

Every article submitted to Lekesan will not have any 'Article Processing Charges'. This includes submitting, peer-reviewing, editing, publishing, maintaining and archiving, and allows immediate access to the full text versions of the articles

\section{SUBSCRIPTIONS}

Lekesan: interdisciplinary journal of asia pasific arts is available in electronic and print formats. Subscribe to gain access to content from the current year and the entire backlist.

Contact us penerbitan@isi-dps.ac.id

\section{CHIEF EDITOR}

Ni Luh Desi In Diana Sari, Indonesia Institute of The Art Denpasar, Indonesia

\section{EDITORIAL BOARDS}

I Wayan Dibia, Indonesia Institute of The Arts Denpasar, Indonesia

I Nyoman Sedana, Indonesia Institute of The Arts Denpasar, Indonesia

Nyoman Darma Putra, Udayana University, Indonesia I Gusti Ngurah Ardana, Indonesia Institute of The Arts Denpasar, Indonesia

Setiawan Sabana, Bandung Institute of Technology, Indonesia Deny Tri Ardianto, Sebelas Maret University, Indonesia M. Dwi Marianto, Indonesia Institute of the Arts Yogyakarta, Indonesia

Sumandiyo Hadi, Indonesia Institute of the Arts Yogyakarta, Indonesia

I Gusti Made Sutjaja, Indonesia

Adrian Vickers, Sydney University, Australia

Diane Butler, Udayana University, Indonesia Jean Couteau, Sarbonne University, France

Mary Louise Totton, Western Michigan University, USA

Faizah Sari, Surya University, Indonesia

\section{ADVISOR BOARDS}

I Gede Arya Sugiartha, Rector of Indonesia Institute of The Arts Denpasar, Indonesia

I Wayan Adnyana, Head of Institution of Research Community Service and Education Development, Indonesia Institute of The Arts Denpasar, Indonesia

\section{WEB ADMIN}

Agus Eka Aprianta

\section{SECRETARIAT}

I Gusti Ngurah Ardika

I Putu Agus Junianto

Ni Putu Nuri Astini

\section{FRIENDS OF LEKESAN}

Andy Mcneilly

Shigemi Sakakibara

\section{DISCLAIMER}

The authors, editors, and publisher will not accept any legal responsibility for any errors or omissions that may have been made in this publication. The publisher makes no warranty, express or implied, with respect to the material contained herein. 




\title{
Lekesan: Interdisciplinary Journal of Asia Pasific Arts
}

Journal homepage http://jurnal.isi-dps.ac.id/index.php/lekesan

\section{Drawing Pattern On Novels In Contemporary Art}

\author{
Jana, I. M. ${ }^{1}$, Sujana, I. W.', P. Muka., I.K. ${ }^{2}$
}

This study is prompted by the concern over stagnant rates of creation in producing contemporary statues in Bali, both in the northern and southern regions, by using stone, wood, and metal mediums. The technology of using gips (plaster of Paris) is easier in statue production, however dismisses innovation in the process. The researcher took interest in I Wayan Sujana's 10 years long research (2007-2017) on transferring of the unconscious onto art from novels (books). Based on that research I Wayan Sujana produced thousands of drawings with rich periodicity patterns. Those patterns are reviewed and selected to be made as contemporary statues. The production method for the contemporary statues, using Drawing Pattern on Novel, was participatory, involving traditional art carving experts. User Participation Method, an approach with user involvement in the art, judgment and creation methods by SP Gustami, was employed to conduct this study. The data was gathered with interviews, observation, documentation, and then exploration, planning and embodiment. This study aimed to create innovation of the fine arts, based on research, using Drawing Pattern on Novels, and can be recognized as part of Indonesian fine arts development. Indonesian contemporary fine arts focuses on local genius as the spirit of its creation. This research generated innovative statutes from stone with Indonesian national culture's aesthetic motifs.

Key words: Drawing on Novel, Statue, Innovative

\footnotetext{
${ }^{1}$ Indonesia Institute of Art, Denpasar, Department of Craft Art.

${ }^{2}$ Indonesia Institute of Art, Denpasar, Faculty of Fine Arts and Design.
} 


\section{INTRODUCTION}

This study is concerned about the phenomenon of contemporary rock, wood and metal sculpture's production that has been stagnated, in both northern and southern Bali with the presence of sculpture printing technology that uses casts (plaster of Paris). This type of casting technology makes it easier to replicate statues, but also has the effect of eliminating the innovation in the creation of new and unique styles of statues. There are no innovative patterns and designs produced. The government in this case, (Ministry of Industry) through the BCIC (Bali Creative Industry Center) has made a development breakthrough in the field of design, in collaboration with ITS Surabaya, to mentor Indonesian youth in Denpasar, Bali, with a twoyear mentoring program (2015-2016). One of the mentors in thatprogram was research member I Wayan Sujana. Because of the limited time, and research funds, the program has not yet been able to assist sculptors. This should immediately be addressed by taking action in the form of implementing innovative designs for sculptors.

The existence of art in the current era of globalization, especially sculpture, is the pride and diplomacy of the nation in the eyes of the international community. Traditionally, sculpture is able to provide aesthetic meaning and philosophy of local wisdom that is useful in teaching young generations about culture. The maintenance of local philosophical values such as cultural diversity, tradition and nationality) are anticipated negative impacts of modernization. Various activities can be carried out, such as sports activities and cultural arts, so they can deliver positive impacts (respect the values of diversity and the values of local wisdom) to our young generation. One of the activities is creating statues through new designs and patterns with classic motifs.

The low rate of innovative sculptures being created is a problem that needs to be addressed immediately. Most of the sculptures circulating in Bali currently are reproductive sculptures made in China, with non-local images and non-local materials, for example, images of Buddha, and the use of non-local metal materials. This phenomenon is worrying because it can put our own culture's heritage in jeopardy. Bali as an international tourist destination may gradually lose its own culture. This is happening generally through its loss of artistry, and specifically in sculpture losing its innovation. Because of this, the author is very interested in the research conducted by I Wayan Sujana over the past 10 years (2007-2017) where he used the pages in old novels and other books to construct an unconscious, and creative space to work in. From the research, I Wayan Sujana produced thousands of drawings on the pages of old books and novels that readers had left behind. He used charcoal as a tool to express imaginative patterns and forms which are very rich in periodicity. These drawing patterns were studied and selected and transformed into contemporary sculptures. A participatory method of creating processes for the production of this style of contemporary sculpture was used. Traditional sculptors worked to create innovative sculptures based on the "Drawing on Novel" patterns. The research and its implementation were able to influence Balinese sculptors who left their careers as sculptors to re-pursue the sculptural art that they once did. Researchers are experts in the field of fine arts, especially sculpture and craftsmanship, using stone, wood and metal mediums. While the other team members had expertise in the field of fine arts, both theoretically and in practicee as design experts, sculpture experts, craft experts, and pure art experts, from across study programs/departments. The concept of innovative research-based artwork (Drawing on Novel), is expected to be recognized as part of contemporary art development of Indonesian, focuses on local wisdom as the spirit of its creation.

In the preliminary studies, this creation will be focused on field research, exploring in-depth and holistic sources of data relating to carvings, and carved ornamental archipelago patterns both in the form of literature and artifacts. Research results include excavation, data collection and data analysis. The concept of creation are produced from data analysis. This concept is explored based on the Drawing on Novel pattern design that has been chosen, until it forms unique and interesting forms or patterns. From the results of the research and exploration a seminar will be held to get input from the participants and mentors relating to the content of the research, the concept of creation, and the results of the design patterns produced. For the realization of this initial work, local stone (batu padas) was used, with the reason to facilitate formation. The results of this creation will be presented through exhibitions, workshops and art discussions. Through this presentation in the public space, we hope our society/community will appreciate this innovative art in terms of aesthetics, style, creation, and from the aspect of local values being adhered to in the conception of the work.

\section{B. Creation Ideas}

Looking at what Sujana has done, there is a very deep motivation underlying his choice of novel books as a picture medium. Hundreds of novels left by their readers were transformed into works of art. What Sujana did was to treat the novel as a physical medium for making art. He viewed the meaning in the books was not limited to the author, but also to illustrators, publishers and readers. Based on this, he encouraged to add a layer of meaning to the novel. Sujana found a way to form new meaning from the old novels, which is exploring its visual fiction. Novels are treated as a medium to understand human-writers, comprehend the conditions of ecstasy in pronouncing words, situations and conditions when the spirit of art converges.

Sujana wants to understand human beings in a metaphysical and mystical way, in this case, that professional writers 
are persons who can balance the frequency of the universes energy, or make themselves a medium of entrusted messages, through fictional composition of the world, drama of life, goodness, honesty, truth and philosophical reality. Therefore, this matter is very interesting to be studied and conducted on a deeper level. The activities carried out by Sujana, namely creating images on novels, called fiction, is a way to equalize energy in achieving human-literary spirits. Drawing on pages of novel pages is a kind of ritual to mystically connecting himself with the figure of the author as a metaphysical figure, a form of spirit or energy. The novel that is in the hand of Sujana turns into a ritual functioning artifact and therefore not just a literary work. Thus, he revitalized the original nature of the literature to a myth, or as a form of literary re-mythology. The Drawing on Novel's pattern is a re-enchantment act, returning magical charm to literary works that have become mass print products. Charcoal scratches from Sujana's hand on the pages of the novel book gives a new status of a unique artistic work instead of just an item of mechanical reproduction that has no aura.

The Drawing on Novel technique shows, in addition to the aforementioned, that the novel books have a unique entity and is very suitable with charcoal medium as an expression tool; where using another paper as medium did not do justice to charcoal uniqueness. One can stand, lay down, even tilt the charcoal on the novels paper page, and produce very distinctive scratch characters. This unique combination (charcoal on novel), led to a mental revelation that aroused emotions, giving birth to amazing ideas. To support these creative ideas, Sujana began to hunt for novel books that had been abandoned by their owners, and who were on their last trip to the smelter to be recycled into paper fiber. In this regard, it can be said that work can be done at various points of an objects life. By doing various research and observations in daily life, we can open our eyes to limitless possibilities. Starting Drawing on Novel as a creative activity in the perceived and discovering memory, influences the forms that emerge from the novel, even though the memory does not dominate most of the scratched on the novel's pages, because most of them are imaginative image.

Based on the description above, this research entitled "Drawing on Novel in Contemporary Art" is conducted, related to the background and ideas underlying it. The problems that will be addressed on this research are as follows: 1. How to materialize two-dimensional Drawing on Novel patterns onto three-dimensional forms? and 2. How to form and elaborate various carved motifs from various traditions in the archipelago into one form of creation?

\section{Contemporary Art}

Klaus Honnef in an art perspective (Sabana, 2014: 142), identified contemporary art as a paradoxical change from avant-garde to post avant-garde. Hone mentioned that,
"Contemporary art, as a postmodern symptom was opened up to a new platform for exploration in the world of art. Along with the questioning of tradition of western thinking and its domination, discussion of devity, differences, plurality localness, traditions of 'the other' grew and intensified..." Contemporary art refers to the paradigm that appeared before (modern), a phenomenon that refers to a particular genre and ideology, and has a different tendency from modern art, which is more meaningfully described as postmodernism. Contemporary art is a way to view art as a parallel understanding to postmodernism art. It is inherent in the following characteristics: It often borrows the past for new contexts; it has an eclectic character, its orientation of work on themes, and its freer use of medium. Additionally, it draws on popular culture, covering both low and high art, it is interested in everyday (social) and political events, defining reality, believing in relative communication, has a critical attitude and skepticism about art and its era. It explores issues of social class, race, gender, age, nation, nature, religion, number and so forth. It is also critical of formalism and abstractism, populistism, universality, awareness of local culture, “open” work or contextualization of work, and critical of rationalism (Barret, 1994 ; Sabana, 2002 in Tjetjep Rohendi Rohidi, 2011: 156).

The world of contemporary art voices complexity in people's lives and culture because of level and order changes in local and global levels. The range of concepts, themes, visual languages, icons and mediums of the artist are increasingly broadening and expanding. Therefore, the world of art now witnesses the diversity of visual disclosures of various values and meanings (Sabana, 2014: 177-178). The assessment in the work of contemporary art generally emphasizes realistic problems in their environment. These problems would include various depravity in human and community morals, issues of poverty and social inequality in urban and rural areas, environmental pollution, new feudalism, mass culture, ethnicity, both related to cultural and religious values, and any themes that stimulate the creativity of contemporary artists.

Contemporary art increasingly gets the foundation of discourse, so it develops in various places and rejects the principles of modernism in its principles. In field of practical art, Astri Wright and Joseph Ficher (1990) revealed that, contemporary artists use traditional sources that are rich and still exist in society as a source of art creation. On the one hand, their work raises a strong aesthetic charm, but on the other hand, their work is portrayed as contemporary art with identity (showing local aspects). This is a paradox in the development of modernism outside the West. Nyoman Erawan is a Balinese artist who has insight, understanding, and appreciation toward traditional, cultural and artistic values. His works, in the form of paintings or installations, have strong artistic and aesthetic charm based on local cultural values. With an awareness and apprecia- 
tion of the cultural cosmic, he creatively engages in fine arts with local character (indigenous). He flows his energy of creation into his artwork and brings out humanitarian realities, meaning, function, and its role in art. However, at the same time, it showed that Era wan is very intense in exploring visuals and media. He utilizes local elements and immerses himself into them, as if he had lived in his previous life. Through art, he lives up to the law of karma and reincarnation.

Regarding the objects that become works of art in the context of traditional and contemporary thinking, the author cites the views of Umar Kayam (1978: 256) stating that tradition and contemporary are the basic issues of culture from various cultural regions that then unite into a nation state. Tradition is a group of established cultural values in a period of time. Contemporary ideas are new cultural values that are looking for a figure of establishment. Both are concepts that will touch various fields including art shows (theater). Tradition and contemporary are not two dichotomous facing concepts, but are continuous and contain various possibilities of elemental integration between the two. What Indonesia calls now is really the story of the melting of homogeneity and thus also the familiarity of traditional agrarian society. Then traditional arts in Indonesia have characteristics that are typical of traditional farming communities as well.

Contemporary art in Bali cannot be separated from the development of Indonesian contemporary art. Indonesian contemporary art is a new form of creativity, as the youngest initiative in Indonesian art, which was pioneered by Indonesian youth in a period of colonialism full of darkness. The art created at that period of time was essentially for the nation's independence and filled it with new, brighter art. By contrast, Indonesian contemporary art, as a work of art, aims to fill human soul, in obtaining a wealth of meaning, and deep inner beauty through the results of this form of creativity in modern times. Kusnadi said that, the expression in the works of new art reflects the subtlety of feelings, the richness of intuition and ideas that are channeled through old and new forms of artistic creativity, as human values that are valuable to live (Kusnadi 1979: 141). Indonesian contemporary art is embodied in various themes through the processing of styles, old, and new mediums. The drawing pattern created by Sujana (contemporary artists) will be transformed into the world of contemporary padas stone sculpture, based on the knowledge of the ornamental archipelago. This has become a momentum when art discourse leads to awareness of local identity, and the postmodern epistemology is maturing itself.

\section{DISCUSSION}

In the creation of contemporary sculptural works above, it is a sign of changes in accentuating a form of creation from content to form or style transformation of reality into imag- es time fragmentation into a timeless series of the present. The creation of artwork takes place continuously through eclecticism, reflexivity, self-reference, tricks, randomness, anarchism, fragmentation (play of language), pastiche and allegory (Lyotard in Madan Sarup, 2008: 206). In this way, the great oppressive narratives began to collapse, namely ideologies, and the birth of a cultural paradigm based on skepticism on universal explanatory theories in general. Now humanity has the opportunity to reveal a variety of small narratives (Lyotard in Audifax, 2006: 186).

Some of the central aspects associated with postmodernism in art include elimination of boundaries between art and everyday life; the collapse of hierarchical differences between popular culture and elite culture; stylistic eclecticism and mixing certain codes. The collapse of originality and the view of the art creator as someone who has special intelligence is replaced by the assumption that art is nothing more than repetition. In the creation of works of art is the stylistic norms and methods. The emphasis on stylistic diversity is part of a wider distrust of modern periphery aesthetics. That art emphasizes the deep connection between what is passed as part and not part of itself (Madan Sarup, 2008: 269). A cultural movement took place characterized by opposition to totalitarianism and universalism, with a new tendency towards diversity, abundant direction, overlapping various images and styles, all of which resulted in fragmentation, contradiction and denial of cultural meaning (Audifax, 2006: viii).

Therefore, the artist in creating works of art strives to produce an entity that is unique, rich and can stimulate the audience, giving rise to the possibility of imagination because it is presented beautifully and interestingly. The creation of a sculpture cannot be separated from the visual elements chosen and the principles of organization. This can be said by an artist as a creator and as a communicator. In understanding the drawing pattern on novels, technically there is a process of transforming content and forms of ideas based on two dimensions into three-dimensional forms of art. Artists (sculptors) focus their thoughts and interests to explore, how to technically solve the chosen drawing pattern, so they can produce applicative knowledge that can be used to predict and control the next steps.

This activity needs empirical analysis by conducting an experimental method to create design sketches that can be seen from various directions. Based on selected handdrawn sketches from Drawing on Novel patterns, the sculptor will transfer their insight onto the padas stone medium to create a contemporary sculpture, as a phenomenon of new sculptures in Balinese culture. By understanding and learning the patterns or drawing shapes contained on the novel's pages (as text), observing the arable object, in semiotics, the sculptor is able to perceive a sign/icon in the pattern of drawing on novel and interpret it, and transfer that into a unique and interesting sculpture, which brings 
new meaning.

In this case, there is a common view of compounding of ideas between Sujana as a conceptual drawing pattern with other artists/sculptors so that in the context of creation, which refers to the Drawing on Novel pattern, there is an artistic response and respect for artwork as an aesthetic object. With a reciprocal response, both in the art of Drawing on Novel patterns, and in the form of sculpture and other arts, this is used as a representation method of understanding the course of life which includes the creation of contemporary sculptures (derived from patterns of Drawing on Novel) which is used as the object of study, thus forming a new image in contemporary art. This researchhighly appreciatesthe possibility of existence and equality of various forms of representation of works of art, because each form of difference from each artist, offers contemporary sculptural works that have personal strengths and characteristics in how to understand forms or ideas which comes from the Drawing on Novel pattern.

This activity, as a form of research through imaginative and intellectual work (e.g. the creation of works of art that refers to the 'Drawing on Novel pattern' through a process that reflects investigations of other media) means exploring the reference sources, the form of objects and materials and techniques, and requires high skills of craftsmanship in order to produce quality sculptures. The realization of these works, through a long process of stages, namely: observation, participation by accelerating, and reinterpreting forms of creative work, can be presented to the public and art critics.

Based on the transformation process of the drawing-sculpture pattern above, this research, creation, and presentation of art, opens a space for what others do not think, which is unexpected; the ideas and the results can vary, while there remains possibilities for the realization of the art work. In this study, there are three distinctive traits: intense attention toward the fundamental perception of the Drawing on Novel pattern, an understanding of the possibilities of forms created relating to the art communities or others. In this case, this research instills a material way of thinking, namely articulating knowledge of the Drawing on Novel patterns' referred to and non-propositional trips embodied in sculpture and the process conveyed. Therefore, this artistic research is a way of thinking about creating innovative and creative works in contemporary art products (see figures 1 and 2 above).

Artistic tradition becomes an identity of contemporary sculpture in this study. Fine art is one of the forms of culture in every ethnic group, appearing with distinctive features and characteristics as a reflection of the soul of the people in responding to the environment in meeting their needs. The characteristic of this created artwork becomes an identity. Like the form of sculpture in Irian Jaya, in con-

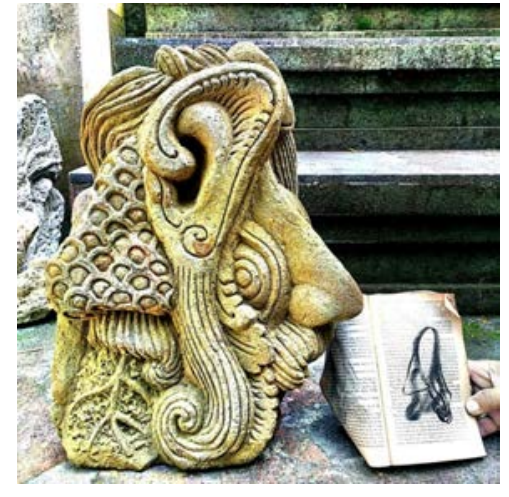

Figure 1. Stone sculpture based on Drawing on Novel pattern (Source: personal document of Made Jana).

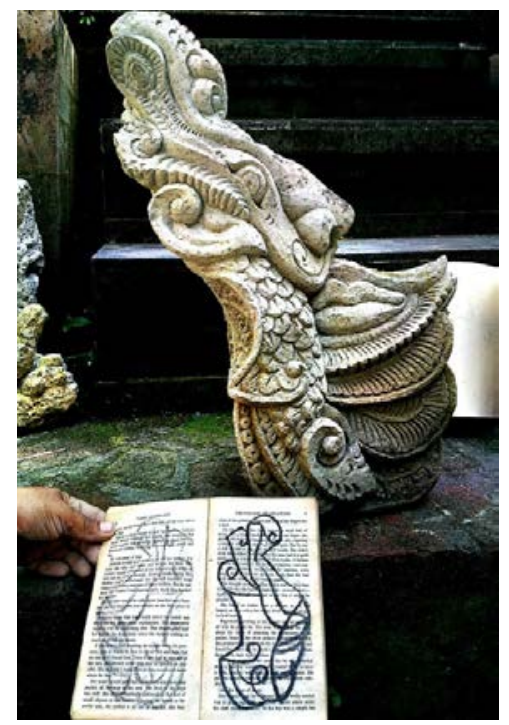

Figure 2. Stone sculpture based on Drawing on Novel pattern (Source: personal document of Made Jana).

trast to the arts in Sumatra, Java, Sulawesi and Kalimantan, and others, passed down from generation to generation without undergoing change. This form of art is known as traditional art. The wealth of traditional art owned by the Indonesian people, as an asset, can be explored and internalized more deeply to be used as a foundation in the work of art. In this art research and creation, traditional arts are still a reference in the creation and basis of thinking. It is well realized that the journey of a tradition always changes internally. That tradition must live and develop. Then dialectically, there are variations in shape and scope of the field of cultivation within the limits of tolerance. The life of a society is always supported by tradition, but the tradition is not something static (Sedyawati, in Tangsi, 2000: 94). Related to the above, Bali as a world tourism destination has caused Balinese people to have interacted with many forms of modern art, both those coming from foreign cultures and domestic cultures. This also results in inter-tribal relations through democratic media, namely Indonesian and foreign languages. In this case, there is 
an expansion of cultural expression as the foundation of contemporary culture, especially in art. Those artists never close themselves to the influence of modern cultural arts that come from outside, who have different cultural backgrounds.

As mentioned by Claire Holt (year of publication?), whatever and wherever the direction of art life in Bali can occur in the future, that with a Balinese sense that is very strong, develops with forms, discoveries, and is supported by the skills of the artists and craftsmen, will bring new surprises in the future (Holt, 2000: 267). The art tradition has undergone a change, which has an impact on the style of sculpture, and continues to develop in the regions by carrying their own identity. The carved styles displayed, are still evident in the characteristics of temples carvings/decorations, gates and sacred buildings. It still shows a vibrant quality and distinctive decorative properties. Therefore, with its local wisdom, traditional arts in Bali can support artists, and present or lay the foundation for innovations as the beginning of new traditions, or in other words as the basis for the development of modern art and contemporary art.

Based on the above description, sculpture works that refer to the Drawing on Novel pattern, are constructed with a new appearance, through the accentuation of decorative lines, primitive shapes, and with the expression of free sculpture techniques. Aspects of community empowerment that are achieved through traditional sculptures and sculptors are creative activities carried out in the community, which are able to mobilize the community towards improvements in quality of life including the economy and knowledge and skills in the area of sculpting. Of course, the aspects of the social approach are the key to the success of these activities. An activity that produces contemporary sculptural products that refer to the on-line drawing pattern is a vehicle for community empowerment. It turns out that this approach is an innovative sculptural development activity responded well by the community. In this case, it has involved interested people, communities, current and former sculptors who have left their profession, and academics, who have all participated in developing contemporary sculpture.

In this case, there is a shift in values and forms, namely giving birth to new ideas and forms of art, which have been separated from the traditional art or classical art. There has been a change both in form and function, as well as content and presentation techniques. Even so, however profound the influence that engulfs Balinese art, especially art, still receives support from the community. Therefore, experts and artists in the field of arts and culture, still have an important role in the art life of Balinese people. Moreover, in the atmosphere and dynamics of Indonesian art and culture, especially the climate of art in Bali, the role of art and culture experts is taken into account. That their artistic thoughts and concepts contribute color to the dynamics and existence of Balinese art today. For example, the Bali Arts Festival has now become a prestigious forum for the preservation and development of art, and cannot be separated from the originators and thinkers who influence Balinese art and culture.

In contemporary sculptural works, the relationship with creativity is based on experimenting and exploitation of excellence and uniqueness of padas stone material as a medium that is irregular in shape, developed into works of art (especially sculpture) has originality and function values the new one. One of the characteristics of this approach is a strong courage and sensitivity in perceiving and interpreting the patterns or shapes of sketches contained in the novel then transferred into padas stone material. Of course, that is a consideration for sculptors; the selection of the drawing pattern form is adjusted to the form of $p a$ das materials that are used as a basis for sparking these ideas. With a creative approach capable of producing good contemporary sculptures, supported by the ability of skill and high wisdom in processing or treating material, this will be able to provide high added value to a material (such as stone).

In performing art observations especially sculpture work which employs the "Drawing on Novel" patterns, from this discussion, it is very important to borrow an opinion from Filman Burke, in the Art Trilogy book written by Soedarso, SP., about the difference in "visual form" with "aesthetic structure" that is first concerning art: an existence that can be seen. While the second, observations of art objects, which are visible to the eye, are strongly influenced by conditions, the means of sight, in addition to various other things. Related to that, the "visual form" is objective and "aesthetic structure" is subjective (Soedarso, SP., 2000: 157).

Observation of art is an active action and even creative. The results of these actions are largely determined by the integration between sensory and projections or "psychological expectations" caused by objects of perception, such as: 1. Visual elements of sculpture; 2. Sculpture design; 3. Art sculpture objects; 4. Visual forms of sculpture; 5. Perceptions of sculpture; 6. Aesthetic experience in sculpture; 7. Aesthetic Structure in sculpture.

The development of new (sculptural) artworks breathes local identity and is based on the richness of Indonesian natural and cultural resources. This concept is at odds with the many circulating mass produced sculpture works from outside Bali. The result is a stagnation in the creation of new and unique sculpture. With the development of an innovative sculpture design that identifies Indonesian culture, as a sign of participating in the process towards a major activity in building a national identity. From an economic point 
of view, local identity is an asset that can be sold. The development of forms of art (sculpture) requires a strong and resilient mentality, supported by a variety of training activities in mastering techniques and skills (craftsmanship) regarding a material. This kind of development is an effort to preserve and refine traditional techniques by applying new techniques, based on the principles of environmental sustainability. Therefore, with the mastery of good knowledge and skills wouldallow sculptors to produce quality sculpture, to achieve a cultural identity, and easily recognizable by the quality produced, without leaving its local genius. Sculpture has a strong tradition base in Indonesia. This type of art is one of Indonesia's cultural treasures that has potential to improve the economy of sculptors/ lower layers of society. Therefore, this art will be pursued and preserved. Thus, by utilizing the tradition base to grow, develop, and to strengthen the economy of the community. Based on the above explanation, it is necessary for sculptors/designers/artists who have the knowledge and skills in creating works of art, giving enlightenment, fostering innovative designs (sculpture) to provide dynamic changes in the world of art. With activities like this, sculptors gain new experiences, which can be useful for the creative process in the creation of innovative works of art (sculpture).

\section{REFERENCES}

Acep Iwan Saidi (2008), Narasi Simbolik Seni Rupa Kontemporer Indonesia, Penerbit: ISACBOOK Yogyakarta.

(2017), Desain Media \& Kebudayaan, Penerbit: ITB. Bandung.

Aprinus Salam (Editor, 1998), Umar Kayam dan Jaring Semiotik, Penerbit : Pustaka Pelajar Yogyakarta.

Ardana, I Gusti Gede (2007), Pemberdayaan Kearifan Lokal Masyarakat Bali Dalam menghadapi Budaya Global, Pustaka Tarukan Agung, Fakultas Sastra Universitas Udayana.

Ardika, I Wayan (2007), Pusaka Budaya dan Pariwisata, Pusaka Larasan, Denpasar Bali.

Andryanto Rikrik Kusmara (2011), Medium Seni Dalam Medan Sosial Seni Rupa Kontemporer Indonesia (Disertasi) Program Studi Ilmu Seni Rupa, Institut Teknologi Bandung.

Audifax (2006), Imagining Lara Croft: Psikosemiotika, Hiperealitas, dan Simbol-simbol Ketaksadaran, Penerbit Jalasutra Yogyakarta.

Bourriaud, Nicolas. (2002) :Relational Aesthetics. Les Presses du reel, Paris.
Capra, Fritjof. (2008) :The Hidden Connections: Startegi Sistemik Melawan Kapitalisme Baru.Terj. Andya Primanda. Penerbit Jalasutra. 74

Claire Holt, (2000), Melacak Jejak Perkembangan Seni Di Indonesia, Pengantar dan Alih bahasa, oleh R. M. Soedarsono, Masyarakat Seni Pertunjukan Indonesia

Guntur (2016), Metode Penelitian Artistik, Cetakan II, Penerbit ISI Press Surakarta.

Hawkins, Alma M. disadur oleh Sumandiyo Hadi,Y. 2003 Mencipta Lewat Tari, Manthili, Yogyakarta.

Jean-Paul Sartre (2000), Psikologi Imajinasi, Penerbit: Yayasan Bintang Budaya, Yogyakarta.

Joseph Fischer (Edit. 1990), Modern Indonesian Art, Three Generations of Tradition and Change 1945-1990, Jakarta and New York: Panitia Pameran KIAS (1990-91) and Festival of Indonesia, 1990.

Kutha Ratna Nyoman, (2007), Estetika Sastra dan Budaya, Pustaka Pelajar Yogyakarta.

Rohedi, Tjetjep Rohendi (2011), Metodologi Penelitian Seni, Penerbit: Cipta Prima Nusantara Semarang.

Sabana, Setiawan (2014), Perspektif Seni, Penerbit Garasi 10 , Bandung.

Sarup, Madan (2008), Panduan Pengantar Untuk Memahami Postrukturalisme dan Postmodernisme, Penerbit Jalasutra Yogyakarta.

Suryabrata, Sumadi. (1983) :Psikologi Kepribadian. CV. Rajawali, Jakarta.

Sutrisno Hadi. 1987. Metodologi Reserch, Fakultas Psikologi Universitas Gajah Mada, Yogyakarta.

Tabrani, Primadi. 2006. Kreativitas \& Humanitas. Sebuah Studi Tentang Peranan Kreativitas Dalam Perikehidupan Manusia. JALASUTRA Yogyakarta.

\section{Exhibition Catalog}

Asmudjo Jono Irianto \& Dinni Tresnadewi NF, (2014, Kuratorial) pameran PARX, Melihat Indonesia, Gallery, Museum, Theater Ciputra Artpreneur, 2014.

Arif Bagus Prasetyo (Kuratorial, 2017) Dari Drawing on Novel Ke Intermingle, dalam Intermingle Art Project: Light Patterns, Bentara Budaya Bali. 
Dibia I Wayan (2017) Pertunjukan Seni Multi Rupa: Sebuah Pengantar Karya Tunggal I Wayan Sujana (SUKLU) Sambutan dalam Intermingle Art Project: Light Patterns, Bentara Budaya Bali.

Hartanto (Kuratorial, 2017), Senyawa Dalam Seni Rupa, dalam Intermingle Art Project: Light Patterns, Bentara Budaya Bali.

Restu Gunawan (Direktur Kesenian), 2017) Sambutan dalam Intermingle Art Project: Light Patterns, Bentara Budaya Bali.

Rizki A. Zailani (Kuratorial, 2017), SKALA:Trienal Seni Patung Indonesia \#3, di Galeri Nasional Indonesia.

Setiawan Sabana (Kuratorial, 2014), Paperium 4, Fiber To Paper, Museum Tekstil Jakarta.

Warih Wisatsana (Sambutan, 2017), Rumah Kaca Nagasepaha Dan Batu Balah, Pameran Lukisan Kaca Wajah Zaman Dalam Kaca, Memperingati 35 Tahun Bentara Budaya 1982-2017.

Dibia I Wayan (2017) Pertunjukan Seni Multi Rupa: Sebuah Pengantar Karya Tunggal I Wayan Sujana (SUKLU) Sambutan dalam Intermingle Art Project: Light Patterns, Bentara Budaya Bali.

Hartanto (Kuratorial, 2017), Senyawa Dalam Seni Rupa, dalam Intermingle Art Project: Light Patterns, Bentara Budaya Bali.

Restu Gunawan (Direktur Kesenian), 2017) Sambutan dalam Intermingle Art Project: Light Patterns, Bentara Budaya Bali.

Rizki A. Zailani (Kuratorial, 2017), SKALA:Trienal Seni Patung Indonesia \#3, di Galeri Nasional Indonesia.

Setiawan Sabana (Kuratorial, 2014), Paperium 4, Fiber To Paper, Museum Tekstil Jakarta.

Warih Wisatsana (Sambutan, 2017), Rumah Kaca Nagasepaha Dan Batu Balah, Pameran Lukisan Kaca Wajah Zaman Dalam Kaca, Memperingati 35 Tahun Bentara Budaya 1982-2017. 